\title{
DEGRADASI SENYAWA DIKOFOL DALAM PESTISIDA KELTHANE 200 EC SECARA FOTOLISIS DENGAN PENAMBAHAN TiO${ }_{2}$-ANATASE
}

\author{
Safni $^{1}$, Desmiati ${ }^{1,2}$, Hamzar Suyani ${ }^{1}$ \\ ${ }^{1}$ Laboratorium Kimia Analitik Terapan, FMIPA Universitas Andalas Padang \\ ${ }^{2} S M A 2$ Padang \\ email: safni@yahoo.com
}

\begin{abstract}
This research is conducted to know whether dicofol compound in Kelthane 200 EC pesticide can be degraded with photolysis method by adding $\mathrm{TiO}_{2}$-anatase. Photolysis method is conducted by using UV 10 watt lamp at the wavelength of $365 \mathrm{~nm}$. The result shows that photolysis method could degrade the dicofol compound at $30 \mathrm{mg} / \mathrm{L}$ concentration as $9.73 \%$ after 60 minutes irradiation. Paraquat compound with the similar concentration by adding $30 \mathrm{mg}$ unmixed $\mathrm{TiO}_{2}$-anatase could degradade $32.51 \%$ after 60 minutes irradiation and $65.84 \%$ by mixing $\mathrm{TiO}_{2}$-anatase. Furthermore, dicofol with the same concentration and $\mathrm{TiO}_{2}$-anatase addition could $86.13 \%$ after 180 minutes irradiation.
\end{abstract}

Keywords : degradation, photolysis, dicofol, anatase-TiO $\mathrm{O}_{2}$

\section{PENDAHULUAN}

Kemajuan teknologi di bidang pertanian telah membuka peluang yang sangat luas bagi penggunaan pestisida. Akan tetapi penggunaan pestisida yang mengandung bahan aktif tertentu secara terus menerus dan tidak memperhatikan petunjuk serta saran penggunaannya dapat mengancam keselamatan lingkungan karena keberadaan residu dari bahan aktif pestisida yang tertinggal di dalam tanah dan di dalam air dapat berpotensi menimbulkan masalah lingkungan yang serius.

Dikofol merupakan salah satu senyawa pestisida yang tergolong akarisida organoklor, berbentuk pekatan jernih berwarna coklat kuning. Dikofol diklasifikasikan sebagai akarisida racun kontak untuk mengendalikan hama serangga, tungau pada tanaman cabai, kapas dan teh.

Kandungan bahan aktif dalam pestisida Kelthane 200 EC adalah dikofol sebanyak 191 g/L. Dikofol merupakan senyawa kimia yang termasuk golongan organoklor. Rumus umum dikofol adalah $\mathrm{C}_{14} \mathrm{H}_{9} \mathrm{Cl}_{5} \mathrm{O}$, memiliki berat molekul 370,51 g/mol. Nama kimia dikofol berdasarkan IUPAC adalah 1,1-bis (4chlorophenyl) 2,2,2-trichloroethanol.

Perkembangan teknologi pertanian yang melibatkan penggunaan senyawa dikofol akan menyebabkan semakin banyaknya residu dari golongan senyawa ini yang terakumulasi di alam. Hal ini dapat menimbulkan efek yang serius pada lingkungan seperti perairan pantai, danau dan badan-badan air (sungai) yang berada di sekitar daerah pertanian tersebut. Oleh karena itu, diperlukan suatu usaha penanganan residu yang tepat dari pemakaian pestisida ini agar residu senyawa tersebut tidak terakumulasi di alam.

Pengolahan limbah secara konvensional telah dilakukan seperti dengan cara pengendapan dan penyerapan dengan karbon aktif atau diproses secara mikrobiologi. Akan tetapi pengolahan limbah dari residu pestisida secara konvensional kurang efektif. Salah satu alternatif dalam menjawab permasalahan tersebut adalah dengan proses oksidasi lanjut (AOPs; Advanced Oxydation Process), fotokatalisis merupakan bagian dari proses ini $^{[1]}$. Penguraian senyawa organik seperti sisa pestisida pada lingkungan dengan penggunaan 
$\mathrm{TiO}_{2}$ sebagai fotokatalis menarik banyak minat peneliti karena metoda ini memiliki keunggulan antara lain mudah ditangani dan efisiensinya tinggi.

Fotokatalisis merupakan suatu proses yang dibantu dengan adanya sinar Ultra Violet dan material katalis. Sebagian besar senyawa organik di dalam air dapat dioksidasi menjadi mineral yang komplit seperti $\mathrm{CO}_{2}$ dan $\mathrm{H}_{2} \mathrm{O}^{[2]}$. Penelitian ini dilakukan untuk mengetahui seberapa besar efektifitas dan efisiensi fotolisis dengan penambahan $\mathrm{TiO}_{2}$-anatase dapat mendegradasi senyawa dikofol.

$\mathrm{TiO}_{2}$-anatase adalah fotokatalis yang efektif digunakan untuk mendegradasi senyawasenyawa organik toksik ${ }^{[3]}$. Hal ini terbukti dari beberapa hasil penelitian tentang zat warna, seperti Sudan I terdegradasi $100 \%$ setelah diiradiasi selama 180 menit dengan penambahan $\mathrm{TiO}_{2}$-anatase ${ }^{[4]}$, napthol blue black terdegradasi sebesar $100 \%$ setelah diiradiasi selama 60 menit dengan penambahan $\mathrm{TiO}_{2}$-anatase ${ }^{[5]}$ dan alizarin terdegradasi sebesar $100 \%$ setelah diiradiasi selama 30 menit dengan penambahan $\mathrm{TiO}_{2}$-anatase ${ }^{[6]}$.

Metoda fotolisis dengan penambahan $\mathrm{TiO}_{2-}$ anatase telah terbukti dapat mendegradasi beberapa zat warna seperti dijelaskan di atas. Dalam penelitian ini akan dilakukan proses degradasi terhadap pestisida dengan bahan aktif dikofol yang banyak digunakan dibidang pertanian, menggunakan metoda fotolisis dengan penambahan $\mathrm{TiO}_{2}$-anatase.

\section{METODOLOGI}

\section{Alat dan Bahan}

Alat yang digunakan yaitu spektrofotometer UV-Vis (S.1000 Secoman, Sarcelles Perancis), untuk mengukur absorban larutan dikofol. Kotak iradiasi yang dilengkapi dengan lampu UV 10 watt, $\lambda=365 \mathrm{~nm}$ (Germicidal CE G 13 Base 8 FC11004) tempat melakukan iradiasi, neraca analitik, sentrifuse dengan kecepatan $6.000 \mathrm{rpm}$ (profuge, model. PRF $6 \mathrm{KP}$, Korea) digunakan untuk memisahkan $\mathrm{TiO}_{2}$-anatase dari sampel, pipet takar, labu ukur, erlenmeyer, magnetik stirer (SRS 116 AA Advanced) sebagai pengaduk dan peralatan gelas lainnya.
Bahan kimia yang digunakan yaitu senyawa dikofol dalam pestisida Kelthane 200 EC (PT. Dow Agrosciences Indonesia) dengan kandungan bahan aktif dikofol $191 \mathrm{~g} / \mathrm{L} \mathrm{TiO}_{2-}$ anatase (Ishihara Sangyo, Ltd. Japan), akuades dan etanol (Merck KGaA 64271 Darmstadt, Germany).

\section{Prosedur}

Larutan Kelthane 200 EC dengan konsentrasi $30 \mathrm{mg} / \mathrm{L}$ difotolisis dengan variasi waktu, $\mathrm{TiO}_{2}$-anatase, dan pengadukkan. Setelah proses fotolisis, larutan disentrifus selama 15 menit untuk memisahkan $\mathrm{TiO}_{2}$-anatase. Selanjutnya diukur serapan larutan Kelthane 200 EC dengan menggunakan spektro-fotometer UV/Vis. Adanya perbedaan serapan awal dan serapan larutan setelah proses pendegradasian menunjukkan adanya penurunan kadar dari Kelthane 200 EC dalam larutan.

\section{HASIL DAN PEMBAHASAN}

\section{Data Pengamatan Variasi Pelarut}

Pembuatan variasi pelarut yang digunakan untuk melarutkan dikofol perlu dilakukan karena dikofol tidak larut dalam akuades. Variasi campuran etanol : akuades dengan perbandingan yang berbeda akan diujicobakan untuk melarutkan dikofol.

Dari pengamatan didapatkan hasil sebagaimana terlihat pada Tabel 1. Berdasarkan hasil pengamatan pada Tabel 1, maka selanjutnya perbandingan pelarut yang digunakan untuk melarutkan dikofol pada penelitian ini adalah etanol $:$ akuades $=5: 5$.<smiles>OC(c1ccc(Cl)cc1)(c1ccc(Cl)cc1)C(Cl)(Cl)Cl</smiles>

Gambar 1. Struktur dikofol

\section{Pengukuran Spektrum Serapan Dikofol}

Pengukuran spektrum serapan dikofol 10, 20, $30,40,50 \mathrm{mg} / \mathrm{L}$ (dalam pelarut etanol:akuades) dengan menggunakan spektrofotometer UV- 
Vis. Spektrum serapan masing-masing larutan dikofol dapat dilihat pada Gambar 2. Puncak serapan maksimum yang diperoleh dari hasil pengukuran serapan dikofol berada pada panjang gelombang $266 \mathrm{~nm}$. Selanjutnya dari nilai serapan dapat dihitung nilai absorpsivitas molar ( $\varepsilon)$, yang nilainya spesifik terhadap masing-masing senyawa.

Berdasarkan hukum Lambert-Beer didapatkan nilai absorpsivitas molar rata-rata yang diperoleh dari kelima pengukuran diatas sebesar 6286,81 L mol-1 $\mathrm{cm}^{-1}$. Hubungan linear antara konsentrasi dikofol dengan absorban dapat dilihat pada Gambar 3. Dalam penelitian selanjutnya digunakan larutan dikofol $30 \mathrm{mg} / \mathrm{L}$ sebagai larutan yang difotolisis dan dilanjutkan dengan penambahan $\mathrm{TiO}_{2}$-anatase.

\section{Pengaruh $\quad \mathrm{TiO}_{2}$-Anatase $\quad$ Terhadap Degradasi Dikofol}

Larutan dikofol $30 \mathrm{mg} / \mathrm{L}$ dengan penambahan $0 ; 6,0 ; 12,0 ; 18,0 ; 24,0 ; 30,0$ dan $36,0 \mathrm{mg} \mathrm{\textrm {TiO } _ { 2 - }}$ anatase difotolisis selama 60 menit. Fotolisis yang disertai dengan penggunaan katalis disebut fotokatalis. Pengaruh fotokatalis terhadap proses fototransformasi merupakan hubungan antara iradiasi, katalis dan pengadukan.
Gambar 4 memperlihatkan bahwa persentase degradasi dikofol bertambah dengan bertambahnya berat $\mathrm{TiO}_{2}$-anatase. Pada penambahan $36,0 \mathrm{mg} \mathrm{TiO}_{2}$-anatase dengan waktu fotolisis 60 menit, persentase degradasi dikofol $30 \mathrm{mg} / \mathrm{L}$ diperoleh sebesar 34,16\% Proses iradiasi senyawa dikofol dengan penambahan $\mathrm{TiO}_{2}$-anatase menyebabkan absorpsi sinar UV oleh titanium dioksida dan terjadi perpindahan elektron pita valensi ke pita konduksi sehingga terbentuk pasangan elektron pada pita konduksi $\left(\mathrm{e}_{\mathrm{pk}}^{-}\right)$dan lubang positif pada pita valensi $\left(h^{+}\right.$pv).

$\mathrm{TiO}_{2}$-anatase berperan meningkatkan efisiensi degradasi dikofol. Ketika proses fotolisis berlangsung, terjadi pembentukan radikal $\mathrm{OH}$ yang berperan sebagai spesies reaktif pada proses degradasi. Dengan penambahan $\mathrm{TiO}_{2}$ anatase dapat meningkatkan produksi radikal $\mathrm{OH}$ sehingga lebih banyak dikofol yang berhasil didegradasi. Peningkatan persentase degradasi dikofol terjadi karena semakin banyak dikofol yang diserap pada permukaan $\mathrm{TiO}_{2}$-anatase dengan adanya hole yang bermuatan positif. Hole pada $\mathrm{TiO}_{2}$ akan bereaksi dengan molekul $\mathrm{H}_{2} \mathrm{O}$ atau ion $\mathrm{OH}^{-}$ dan memproduksi radikal hidroksil yang akan mendekomposisi senyawa dikofol.

Tabel 1. Perbandingan Variasi Pelarut

\begin{tabular}{cc}
\hline $\begin{array}{c}\text { Perbandingan Pelarut } \\
\text { (etanol }: \text { akuades) }\end{array}$ & Larutan dikofol \\
\hline $0: 10$ & Keruh \\
$1: 9$ & Keruh \\
$2: 8$ & Keruh \\
$3: 7$ & Keruh \\
$4: 6$ & Bening kekeruhan \\
$5: 5$ & Bening \\
$6: 4$ & Bening \\
$7: 3$ & Bening \\
$8: 2$ & Bening \\
\hline
\end{tabular}




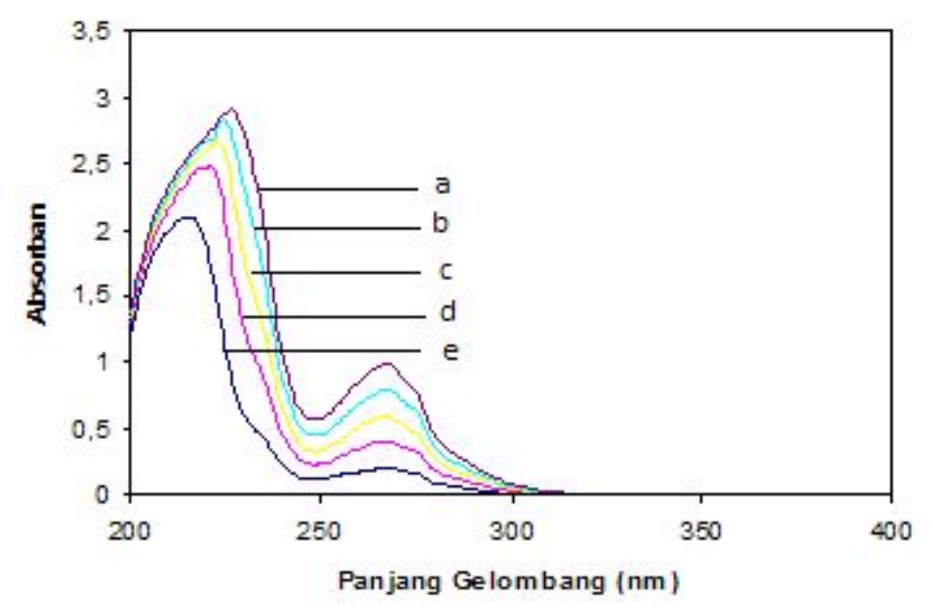

Gambar 2. Spektrum serapan dikofol sebelum fotolisis (a) $10 \mathrm{mg} / \mathrm{L}$ (b) $20 \mathrm{mg} / \mathrm{L}$ (c) $30 \mathrm{mg} / \mathrm{L}$ (d) $40 \mathrm{mg} / \mathrm{L}$ (e) $50 \mathrm{mg} / \mathrm{L}$

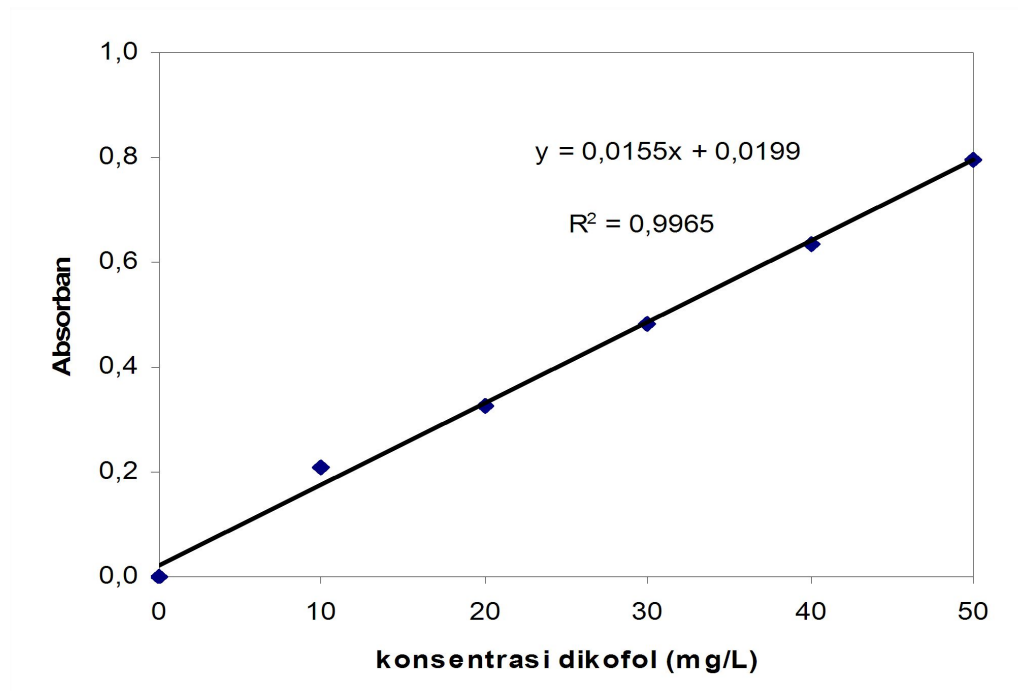

Gambar 3. Kurva kalibrasi standar dikofol

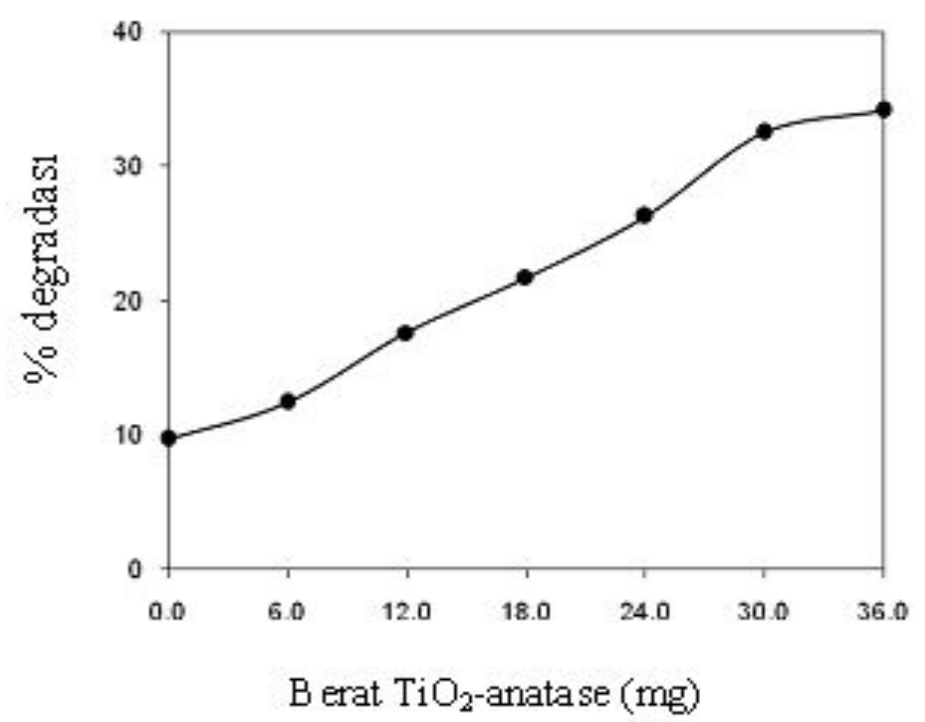

Gambar 4. Pengaruh berat $\mathrm{TiO}_{2}$-anatase terhadap persentase degradasi dikofol Ket: [Dikofol] $=30 \mathrm{mg} / \mathrm{L}$, waktu iradiasi 60 menit. 
Peningkatan persentase degradasi senyawa dikofol yang dilarutkan dalam air yang mengandung ion $\mathrm{H}^{+}$bereaksi dengan $\mathrm{O}^{-2}$ dan akan meningkatkan jumlah $\mathrm{H}_{2} \mathrm{O}_{2}$, akibat meningkatnya jumlah $\mathrm{H}_{2} \mathrm{O}_{2}$ maka jumlah radikal $\mathrm{OH}$ dan $\mathrm{OH}^{-}$yang dihasilkan bertambah.

Banyaknya $\mathrm{OH}^{-}$yang terbentuk akan meningkatkan jumlah radikal hidroksil yang berperan dalam mendegradasi dikofol. Adanya oksigen, substrat atau senyawa yang akan didegradasi tidak mengalami transfer muatan secara langsung, tetapi melibatkan terbentuknya hidrogen peroksida lebih dahulu sebagai sumber radikal hidroksil.

\section{Pengaruh Pengadukan Selama Fotolisis Terhadap Degradasi Dikofol}

Fotokatalis larutan dikofol $30 \mathrm{mg} / \mathrm{L}$ yang ditambah $\quad \mathrm{TiO}_{2}$ disertai pengadukan menggunakan pengaduk magnetik selama 60 menit, menunjukkan peningkatan persentase degradasi, bahkan pada penambahan $36,0 \mathrm{mg}$ $\mathrm{TiO}_{2}$-anatase terjadi kenaikan persentase degradasi yaitu $66,87 \%$. Pada proses iradiasi selama 60 menit yang disertai dengan adanya pengadukan, proses fototransformasi berlangsung lebih baik, karena terjadi pemerataan diseluruh bagian larutan pada saat dikenai sinar dan reaksi antara fotokatalis semikonduktor $\mathrm{TiO}_{2}$ dengan molekul dikofol menjadi lebih sempurna.

Proses pengadukan membentuk keseimbangan proses adsorpsi pada permukaan semi konduktor. Jika proses tidak seimbang (adsorpsi besar dari desorpsi) maka proses masuknya substrat akan terhalang, akibatnya efisiensi fotokatalis menjadi rendah. Di samping itu, pengadukan juga akan sangat membantu proses pelarutan oksigen ke dalam suspensi. Adamson melaporkan bahwa oksigen berperan penting dalam fotokatalis ${ }^{[7]}$, dalam hal ini oksigen berfungsi sebagai akseptor elektron pita konduksi $\left(\mathrm{e}_{\mathrm{pk}}^{-}\right)$pada reaksi:

$$
\mathrm{O}_{2}+\mathrm{e}^{-}{ }_{\mathrm{pk}} \rightarrow \mathrm{O}_{2}^{-}
$$

Ion radikal oksigen dapat memicu reaksi lanjutan dengan radikal hidrogen melalui reaksi berantai (1-8), akan terbentuk suatu radikal hidroksil dan ion hidroksil yang dapat berperan untuk menghancurkan molekul substrat dikofol, dilanjutkan dengan reaksi berantai yang mengakibatkan dikofol mengalami transformasi.

Mekanisme fotolisis semikonduktor melibatkan spesi oksigen ${ }^{[8]}$.

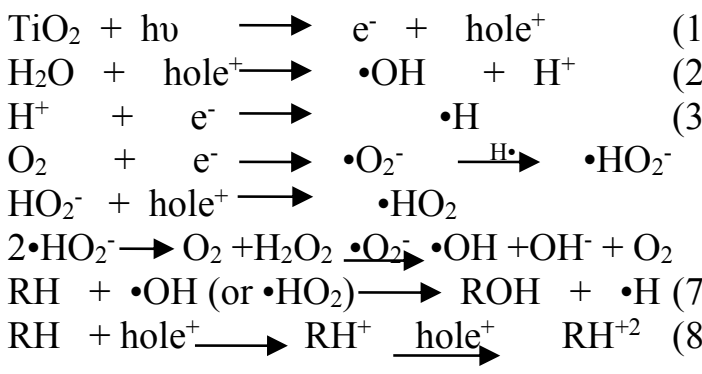

Radikal hidroksil sangat penting dalam fototransformasi dikofol, pembentukannya sangat bergantung pada jumlah oksigen reaktif yang terlibat dalam reaksi. Perbedaan yang cukup signifikan antara persentase degradasi pada proses iradiasi tanpa pengadukan dengan proses iradiasi yang disertai pengadukan dapat kita lihat pada Gambar 5.

Pengadukan menyebabkan partikel $\mathrm{TiO}_{2}-$ anatase tersebar secara merata di seluruh permukaan larutan, sehingga interaksi antara muatan permukaan $\mathrm{TiO}_{2}$-anatase dengan senyawa dikofol lebih sempurna sehingga dalam waktu yang sama dapat mendegradasi senyawa dikofol lebih banyak jika dibandingkan dengan proses iradiasi tanpa disertai pengadukan.

\section{Pengaruh Variasi Waktu Fotolisis Terhadap Persentase Degradasi Dikofol}

Metoda fotolisis dalam proses kimia menghasilkan radikal $\mathrm{OH}$ dalam larutan berair yang akan menyerang senyawa organik untuk mengawali proses mineralisasi. Semakin lama waktu iradiasi semakin banyak jumlah radikal $\mathrm{OH}$ yang berperan dalam mendegradasi senyawa dikofol.

Persentase degradasi dikofol bertambah dengan bertambahnya waktu iradiasi pada senyawa dikofol, seperti terlihat pada Gambar 6. Berdasarkan besarnya absorban awal dan absorban setelah fotolisis maka dapat ditentukan persentase degradasi dikofol. 
Larutan dikofol $30 \mathrm{mg} / \mathrm{L}$ yang telah ditambah dengan $30,0 \mathrm{mg} \mathrm{TiO}_{2}$-anatase diiradiasi dan diaduk selama beberapa variasi waktu yaitu 30 , 60, 90, 120, 150 dan 180 menit.

Dari Gambar 7 dapat dilihat persentase degradasi senyawa dikofol meningkat seiring dengan bertambahnya waktu iradiasi, sehingga pada menit ke 180 senyawa dikofol telah terdegradasi sebesar $86,13 \%$. Data persentase degradasi dikofol pada penambahan $30,0 \mathrm{mg}$ $\mathrm{TiO}_{2}$ berdasarkan variasi waktu.

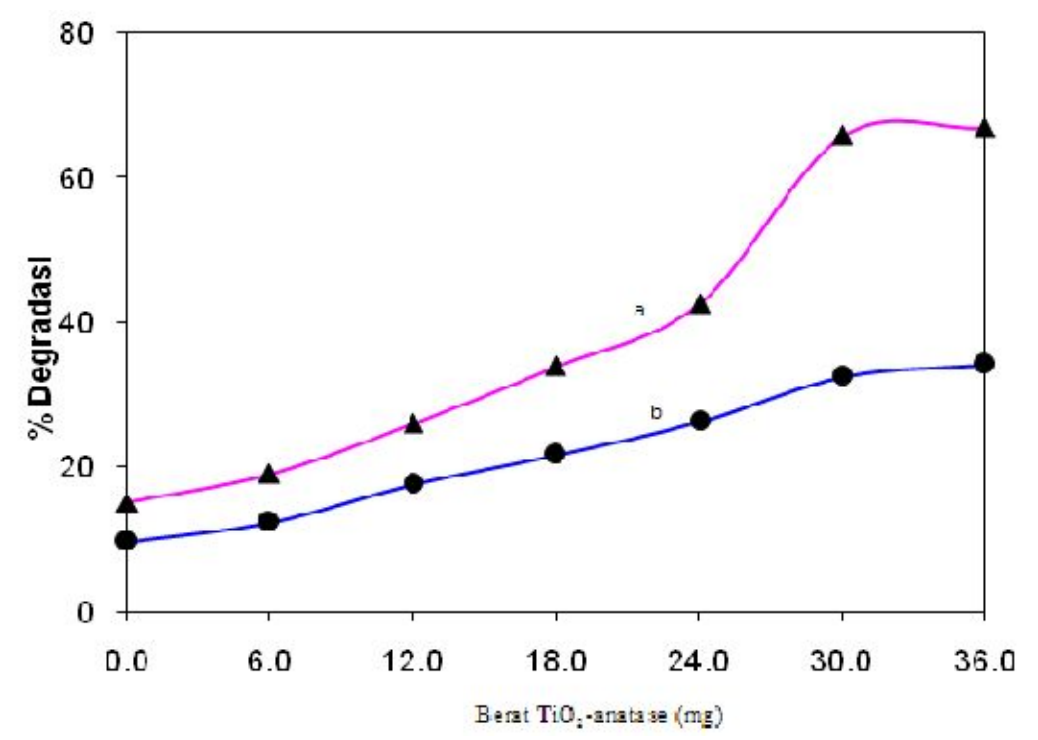

Gambar 5. Pengaruh berat $\mathrm{TiO}_{2}$ - anatase terhadap persentase degradasi dikofol untuk larutan yang diaduk dan tanpa diaduk

Ket: Dikofol] $=30 \mathrm{mg} / \mathrm{L}$, waktu iradiasi 60 menit

(a) Dengan pengadukan (b) Tanpa pengadukan

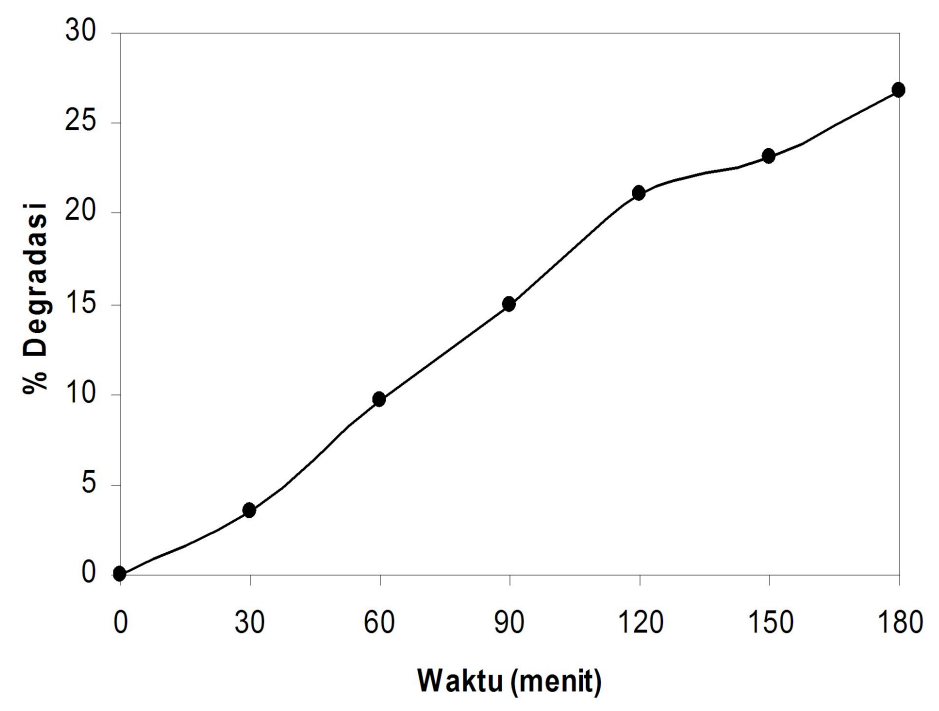

Gambar 6. Pengaruh waktu iradiasi terhadap persentase degradasi dikofol

Ket: [Dikofol] $=30 \mathrm{mg} / \mathrm{L}$, tanpa $\mathrm{TiO}_{2}$-anatase 


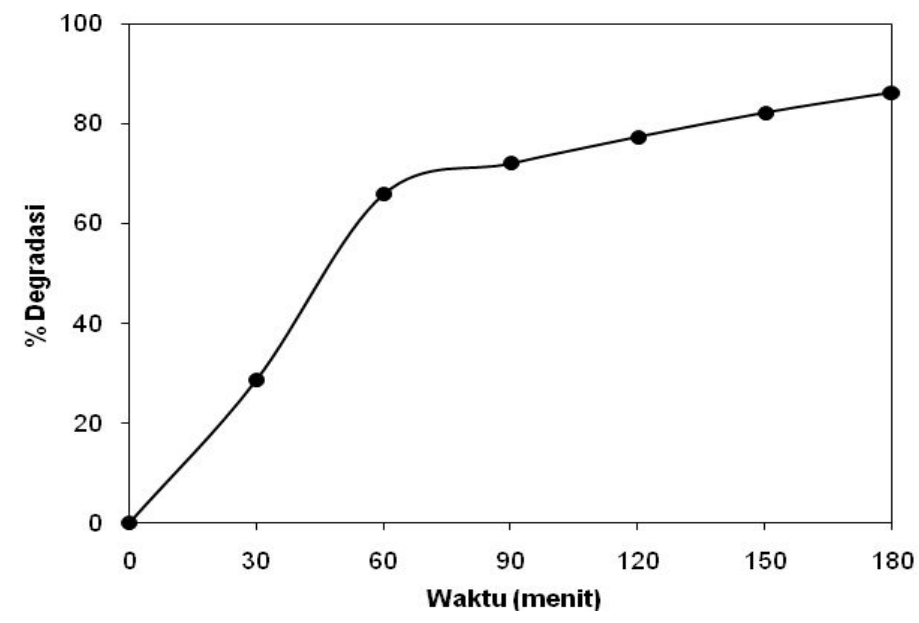

Gambar 7. Pengaruh waktu iradiasi terhadap persentase degradasi

Ket: $\left[\right.$ Dikofol] $=30 \mathrm{mg} / \mathrm{L}$, berat $\mathrm{TiO}_{2}$-anatase $30,0 \mathrm{mg}$. Diaduk selama proses iradiasi

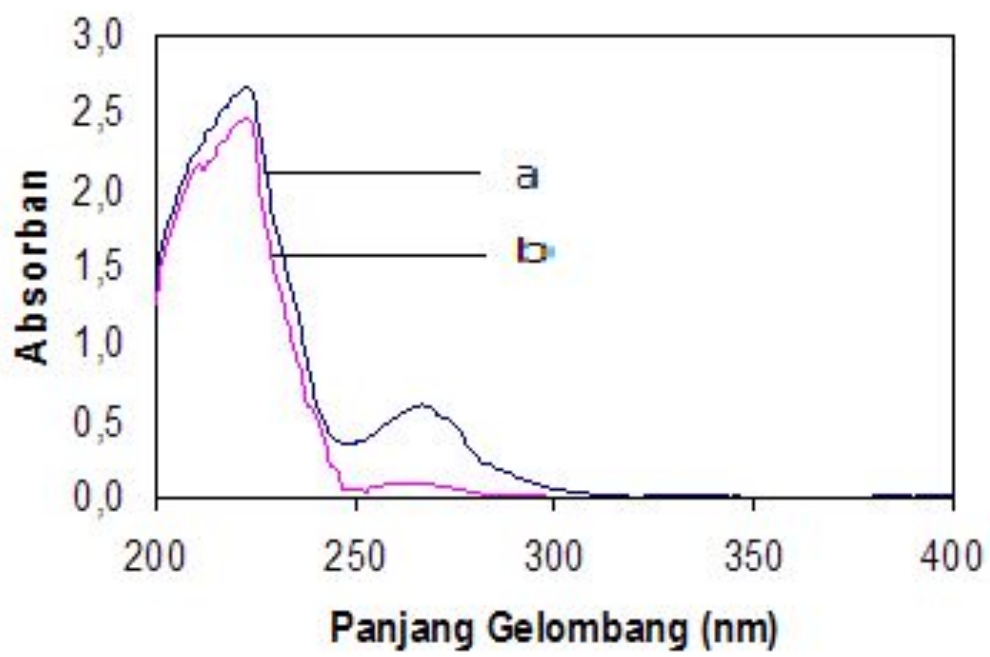

Gambar 8. Spektrum serapan dikofol sebelum dan setelah fotolisis Ket: [Dikofol] $=30 \mathrm{mg} / \mathrm{L}$, (a) Sebelum fotolisis (b) Setelah fotolisis

Dengan pengadukan partikel $\mathrm{TiO}_{2}$-anatase tersebar lebih merata di seluruh permukaan larutan sehingga interaksi antara muatan permukaan $\mathrm{TiO}_{2}$-anatase dengan senyawa dikofol lebih sempurna sehingga dalam waktu yang lebih singkat dapat diperoleh persentase degradasi yang lebih besar jika dibandingkan dengan proses iradiasi tanpa disertai pengadukan. Pada Gambar 8 dapat dilihat spektrum serapan dikofol sebelum dan sesudah fotolisis selama 180 menit dengan penambahan $\mathrm{TiO}_{2}$-anatase sebanyak $30,0 \mathrm{mg}$ disertai pengadukan.

\section{KESIMPULAN}

Metoda fotolisis dengan menggunakan lampu UV 10 watt $(\lambda=365 \mathrm{~nm})$ dapat mendegradasi senyawa dikofol $(30 \mathrm{mg} / \mathrm{L})$ sebanyak $9,73 \%$ dengan waktu iradiasi selama 60 menit. Untuk senyawa dikofol pada konsentrasi dan waktu iradiasi yang sama dengan penambahan $\mathrm{TiO}_{2}$ anatase 30,0 mg terdegradasi sebanyak 32,51\% (tanpa pengadukan) dan $65,84 \%$ (dengan pengadukan) selanjutnya dengan menambah waktu perlakuan menjadi 180 menit, senyawa dikofol $(30 \mathrm{mg} / \mathrm{L})$ dengan penambahan 30,0 $\mathrm{mg} \mathrm{TiO}_{2}$-anatase dapat terdegradasi sebanyak $86,13 \%$. 


\section{DAFTAR PUSTAKA}

1. M. E. Yulianto, D. Handayani dan Silviana, Kajian Pengolahan Limbah Industri Fatty Alkohol dengan Tekhnologi Fotokatalitik Menggunakan Energi Surya, Gema Teknologi 22, 2005.

2. W. S. Kuo, dan P. H. Ho, Solar Photocatalytic Decolorization of Methylene Blue in Water, $J$. Chemosphere, 45: 77-83, (2001).

3. A. Hiskia, M. Ecke, A. Troupis, A. Kokorakis, H. Hennig dan E. Papaconstantinou, Sonolytic, Photolytic, and Photocatalytic Decomposition of atrazin in presence of Polyoxometalates. J. Environ. Sci. Tech., 35: 2358-2364, (2001).

4. Safni, U. Loekman dan F. Febrianti, Degradasi Zat Warna Sudan I Secara Sonolisis dan Fotolisis Dengan Penambahan $\mathrm{TiO}_{2}$-anatase, $J$. Ris. Kim., 1(2): 164-170, (2008).

5. Safni, Maizatisna, Zulfarman dan $T$. Sakai, Degradasi zat warna Naphtol Blue Black secara sonolisis dan fotolisis dengan penambahan $\mathrm{TiO}_{2}$-anatase, J.Ris Kim., 1(1): 43 - 49, (2007).

6. Safni, Z. Zuki, C. Haryati, Maizatisna, Degradasi Zat Warna Alizarin Secara Sonolisis dan Fotolisis Dengan Penambahan $\mathrm{TiO}_{2}$-anatase, $J$. Pilar (Submitted), (2008).

7. A. W. Adamson, Physical Chemistry of Surface, $5^{\text {th }}$ ed, John Wiley \& Sons, New York, 1990, 710-731.

8. T. Kameyama, Robust Science and Technology for Safe and Secure Life Space Photocatalyst, Ainst's Photocatalyst, 2002.

9.

1. W. Andayani dan A. Sumartono, Aplikasi Radiasi Pengion Dalam Penguraian Limbah Industri I, Radiolisis Larutan Standar Zat Warna Reaktif Cibacron Violet 2 R, Majalah Batan, XXXII(1), (1999).

2. S. Arief, Safni dan P. P. Roza, Degradasi Senyawa Rhodamin B Secara Sonolisis Dengan Penambahan $\mathrm{TiO}_{2}$ Hasil Sintesa Melalui Proses Sol-Gel, J. Ris. Kim., 1(1): 64 - 69, (2007).
3. J. S. Fritz dan G. H. Schenk. Quantitative Analytical Chemistr, $4^{\text {th }}$ ed, Allyn and Bacon, Inc, Boston, 1979, 77-90.

4. J. Gunlazuardi dan W. Andayani, Evaluasi Deklorinasi dan Pemecahan Cincin Aromatis Selama Degradasi Pentaklorofenol Secara Fotokatalisis Pada Permukaan Lapisan Tipis Titanium Dioksida, Departemen of Chemistry, University of Indonesia, Kampus Baru UI-Depok, 2002.

M. T. Lasut, B. Polii dan V. A. Kumurur, Komparasi Tingkat Toksisitas Beberapa Pestisida (Endosulfan, Fentoat, BPMC, Glifosat, 2-4 D) Dengan Menggunakan Ikan Bandeng (Chanos Chanos Forsk), Hasil Penelitian, Universitas Sam Ratulangi, Manado, 2001.

A. L. Linsebigler Guangquen Lu, T. John, Yates, Photocatalysis on $\mathrm{TiO}_{2}$ Surface : Principles, Mechanishm and Selected Results, Chem Rev., 95: 735-758, (1995).

M. O' Neil, An Encyclopedia of chemical, Drugs and Biologicals, Merck Index, $13^{\text {th }} \mathrm{ed}$, Merek and Co. Inc, USA, 2001, 1085.

2. H. Park dan W. Choi, Photocatalytic Reactivities of Nafion-Coated $\mathrm{TiO}_{2}$ for The Degradation Charged Organic Compounds under UV or Visible Light, J. Phys. Chem., 109: 11667-11674, (2005).

3. Safni, Zulfarman dan D. F. Wulandari, Degradasi Indigo Carmin Secara Sonolisis dan Fotolisis Dengan Penambahan $\mathrm{TiO}_{2}-$ anatase, J. Sains MIPA (Submitted), (2008).

Safni, Zulfarman, F. Sari, Degradasi Metanil Yellow Secara Sonolisis dan Fotolisis Dengan Penambahan $\quad \mathrm{TiO}_{2}$-anatase, J. Forum Penelitian (Submitted), (2008).

4. D. A. Skoog, D. M. West dan F. J Holler, Fundamental of Analytical Chemistry, $6^{\text {th }}$, Saunders College Publishing, Philadelpia, 1996, 406.

5. S. Sudarmo, Pestisida, Kanisius. Yogyakarta, 1991.

6. Ullman's, Encyclopedia Of Industrial Chemistry, Vol A27, VCH, Verlagesells Chaff, Germany, 1996, 102-104.

7. A. L. Underwood, and R. A. Day, Analisis Kimia Kuantitatif, (Terjemahan Handayana, Pudjaatmaka), Edisi 4, Erlangga, Jakarta, 1988, 523-528. 
